\title{
The Second Fuzzy Layer Comprehensive Evaluation Model of Urban Low-Carbon Developmental Level and Its Empirical Research
}

\author{
Peilin Liu \& Xiuying Shen \\ Hunan Hengyang Normal University, Hengyang 421008, China
}

Received: June 1, 2011

Accepted: July 19, 2011

doi:10.5539/jsd.v4n4p145

Fund Item: Projects of National Natural Science Foundation (40771050), Social science major bidding project in Hunan Province(SKZD1008), Residential environmental research base project in Hunan Province(RJ1001) and "resourcal \& environmental management and regional sustainable development" Science and technology innovation team project in Hunan Province(CXTD1003)

\begin{abstract}
Cities are main places that human activities get together and subjects that greenhouse gases emit. When striving to develop low-carbon economy, each country has attached importance to the construction of low-carbon city; therefore, the city should have its own evaluation index system of low-carbon development level in order to measure its low-carbon developmental level and thus find and solve problems. The article put forward the evaluation index system of urban low-carbon developmental level and the second fuzzy layer comprehensive evaluation model. One medium-sized city in midland was taken for example to carry out empirical research. On the one hand, results of the research show that the model has good universality; on the other hand, they also show that Chinese urban low-carbon developmental level is still very low and it needs to make great effects to prompt urban low-carbon development.
\end{abstract}

Keywords: Urban low-carbonation, Developmental level, The second fuzzy layer, Model

\section{Introduction}

Since UK proposed developing low-carbon economy in 2003, low-carbon economy has become the hot topic and difficult point that theory horizon and industrial circles studied. From the perspective of the source, the origin of low-carbon economy dates back to Boulding's "Spacecraft economic theory" in 1960s, but it was taken as official concept and put forward in British Energy White Paper "Our energy future: creating a low carbon economy". There has not been a strict and unified definition about low-carbon economy at home and abroad. For example, Sun Bolin thinks low-carbon economy is green economy with low pollution, low emission and low energy consumption, which meant to emit the least greenhouse gases in the development while obtaining the largest output in whole society. Wu Changhua thinks, as the centre of human social and economic activities, cities gather over half population of the world and the greenhouse gases emission accounts for about $75 \%$ of the total amount in the world. With increasingly rapid urbanization, urban energy consumption and pollution are serious and urban environmental deterioration in China becomes more obvious. So quite few cities put forward targets to develop low-carbon economy and build low-carbon cities. Some cities prompted the development of low-carbon economy through building low-carbon city and representative area. How to reflect comprehensively the efficiency and effects that a city develops low-carbon economy and systematically embody the gap of developing low-carbon economy in cities in order to revise strategic path in time are key points that need to break through. Practical development needs to do research in the evaluation index system of urban low-carbon economy development. The article adopts the second fuzzy layer comprehensive evaluation method and takes a city in midland for example to assess the development of urban low-carbon economy comprehensively, and corresponding suggestions are put forward.

\section{The structure of second fuzzy layer comprehensive evaluation index system}

Building evaluation index system is the basis of evaluation. To comprehensively assess the development of low-carbon economy in a city, firstly, it is necessary to build a set of systematical factors to quantize criteria. Referring to the low-carbon criteria in cities formulated by China, the authors attempted to build evaluation index system which reflects not only the thoughts of simultaneous and coordinative development between economic development, science and technology progress, social development and environmental optimization, 
but the state and tendency of the development of urban low-carbon economy. According to the target of low-carbon economy and the requirements of building low-carbon city, the construction of evaluation index system of low-carbon economy must follow the principles below: 1) scientificity and comparability principle 2) systematic and hierarchy principle 3 ) pertinence and operability principle

The selection of evaluation index system of urban low-carbon developmental level may adopt to theoretical summary and empirical investigation method. On the one hand, based on related literature retrieval and reading in databases(mainly including PSTP, Wangfang Data, Elsevier, EBSCO, Cell Press Database, SCI, EI Village and so on) at home and abroad, combined the analysis on low-carbon economy theory, recycle economy theory, urban economics and scientific outlook on development, some main factors that have influence on urban low-carbon development are collected; on the other hand, through practical investigation and analysis on governmental department, urban research experts and academic research institutes, some main factors that have influence on urban low-carbon development are collected as shown in table 1.

From table 1 we can see, the evaluation index system of urban low-carbon developmental level are comprised of six-dimension compound system including resource and energy system, economic system, science and technology system, environmental system, social system and low-carbon policy system. In the impact factors of each dimension, on the one hand, many factors have fuzziness, for example, it is difficult to evaluate residential low-carbon concept accurately. Different samples will produce different values. At different time and environment, the same observation object may have different values. Fuzzy evaluation method has its relative advantages on dealing with uncertain problems based fuzzy theory; on the other hand, when carrying out quantitatively measuring urban low-carbon developmental level comprehensively in China, it is necessary to measure quantitatively all the factors in each layer, which means to make a quantification analysis on people's comparative judgment thinking process in many layers. The simple and practical method to deal with this kind of problem is Analytic Hierarchy Process(AHP). Based on that, the authors will adopt the method combined fuzzy set theory and Analytic Hierarchy Process to assess urban low-carbon developmental level in China.

\section{The content and procedure of the second fuzzy layer comprehensive evaluation model}

Suppose U represent comprehensive factors set, V represent evaluation set, A represent the weights set of the first layer factors, $\mathrm{An}(\mathrm{n}=1,2,3, \ldots \ldots)$ represent the weights set of the second layer factors, $\mathrm{R}$ represent all Single factor evaluation fuzzy matrix, $\mathrm{Rn}(\mathrm{n}=1,2,3, \ldots \ldots)$ represent Single factor evaluation fuzzy matrix, B represent the first layer fuzzy comprehensive evaluation set, then the specific operating procedures of evaluating urban low-carbon developmental level can follow the next seven steps:

1) Build the comprehensive factors set of evaluating China's urban low-carbon developmental level $U$

For the comprehensive factors set of evaluating China's urban low-carbon developmental level U, it is a multi-dimension mathematical space comprised of multi-factors. Each element in $\mathrm{U}$ can be single or multi-layer according to their specific characteristics. Suppose $U=\left(\mathrm{u}_{1}, \mathrm{u}_{2}, \mathrm{u}_{3}, \ldots, \mathrm{u}_{\mathrm{m}}\right)$, then, according to the specific situations of $u_{i}$, each $u_{i}$ is divided into several ranks $u_{i j}$ and comprises factors rank set: $u_{i}=\left(u_{i 1}, u_{i 2}, \ldots, u_{i n}\right)$, in which $u_{i j}$ represents the rank $j$ of the factor $i$ in the second layer $(i=1,2,3, \ldots, m ; j=1,2,3, n)$; the meaning of the indexes $u_{i}$ and $\mathrm{u}_{\mathrm{ij}}$ is shown in table 1 .

2) Build evaluation set $V$ that evaluates different layers of factors of China's urban low-carbon developmental level

In factors set, the set of all the possible evaluation results of certain factor comprises evaluation set $\mathrm{V}$, which is the direct characteristic of each layer's factors evaluation results. For the structure of evaluation set V, we may design an investigation form through which the results of each factor are divided into five different ranks. For the factor set of the first layer $U_{i}$ what they represent is developmental level state and it can be shown as: $\mathrm{V}=\left(\mathrm{V}_{1}, \mathrm{~V}_{2}, \mathrm{~V}_{3}, \mathrm{~V}_{4}, \mathrm{~V}_{5}\right)=$ (very low, lower, moderate, higher, very high). Sometimes in order to calculate conveniently, we can suppose $\mathrm{V}_{1}=10, \mathrm{~V}_{2}=20, \mathrm{~V}_{3}=30, \mathrm{~V}_{4}=40, \mathrm{~V}_{5}=50$ and then obtain the final evaluation value of $\mathrm{V}$ through weighed process.

3) Build each layer factor's weight set $A, A_{i}$ that evaluates different layers of factors of China's urban low-carbon developmental level

Suppose the weight set of the first layer's factor $\mathrm{A}=\left(\mathrm{a}_{1}, \mathrm{a}_{2}, \ldots, \mathrm{a}_{\mathrm{m}}\right)$, in which $\sum_{i=1}^{n} a_{i}=1$ the weight set of the

factor $\mathrm{i}$ of the second layer $\mathrm{A}_{\mathrm{i}}=\left(\mathrm{a}_{\mathrm{i} 1}, \mathrm{a}_{\mathrm{i} 2}, \ldots \mathrm{a}_{\mathrm{in}}\right)$, in which $\sum_{i=1}^{m} \sum_{j=1}^{n} a_{i j}=1$ 
For the confirmation of weight set, here AHP method is adopted and its specific procedures have three steps: firstly, adopt 1-7 ratio scale to compare the importance of each two factors in the same layer, then according to the results build judgment matrix $M$ and finally extract the roots of the characteristic equation $M w=\lambda_{\max } \omega$, the solution $\mathrm{w}$ of the equation is the weight which means that the order weight of each factor's relative importance in the layer relative to upper layer's factor.

4) Build each single factor fuzzy judgment matrix $R \sim i$ that evaluates China's urban low-carbon developmental level

Membership $r_{\mathrm{ijk}}$ indicates the degree that all judgers think the factor $\mathrm{U}_{\mathrm{ij}}$ belongs to the rank $\mathrm{V}_{\mathrm{k}}$, and its calculation formula is: $r_{i j k}=$ (the number of judgers who think the factor $u_{i j}$ belongs to the rank $V_{k}$ )/(the total number who participate in judgment), in which $\mathrm{k}-1,2,3,4,5$. If $\mathrm{n}$ indicates the number of factors that each $\mathrm{U}_{\mathrm{i}}$ contains, $\mathrm{m}$ indicates the number of elements in evaluation set $\mathrm{V}(\mathrm{m}=5)$, j indicates the element of the rank $\mathrm{j}$ of the factor I in the second layer $(\mathrm{j}=1,2, \ldots, \mathrm{n})$, the fuzzy judgment matrix $\mathrm{R} \sim \mathrm{I}$ can be shown as:

$$
R_{i}=\left[\begin{array}{lllll}
r_{i 11} & r_{i 12} & r_{i 13} & r_{i 14} & r_{i 15} \\
r_{i 21} & r_{i 22} & r_{i 23} & r_{i 24} & r_{i 25} \\
r_{i 31} & r_{i 32} & r_{i 33} & r_{i 34} & r_{i 35} \\
r_{i 41} & r_{i 42} & r_{i 43} & r_{i 44} & r_{i 45} \\
r_{i 51} & r_{i 52} & r_{i 53} & r_{i 54} & r_{i 55}
\end{array}\right]
$$

5) Calculate the fuzzy comprehensive evaluation sets that evaluates China's urban low-carbon developmental level

According to $A_{i}$ and $R \sim I$, the second layer fuzzy comprehensive evaluation set $R$ is obtained. $B$ has been supposed to represent the first layer fuzzy comprehensive evaluation set and then $B_{i}$ represents the fuzzy comprehensive evaluation set of the factor $I$, so $B_{i}=A_{i} * R_{i}$. If $b_{i k}$ is supposed to indicate the membership of the evaluation subject $U$ to each evaluation element $V$ when comprehensively evaluating the factors $U_{i j}(j=1,2,3, \ldots, n)$ which decide $\mathrm{U}$ in the second layer, $\mathrm{b}_{\mathrm{ik}}=\mathrm{V}\left[\mathrm{a}_{\mathrm{ij}} \wedge \mathrm{r}_{\mathrm{ijk}}\right],(\mathrm{k}=1,2,3,4,5)$, in which $\mathrm{a}_{\mathrm{ij}}$ indicates an element in the factor weight set $\mathrm{A}_{\mathrm{i}}$ of the second layer, so the second layer fuzzy comprehensive evaluation set $\mathrm{R}$ is:

$$
R_{i}=\left[\begin{array}{l}
B_{1} \\
B_{2} \\
\cdots \\
B_{n}
\end{array}\right]=\left[\begin{array}{l}
A_{1} R_{1} \\
A_{2} R_{2} \\
\cdots \\
A_{n} R_{n}
\end{array}\right]=\left[b_{i k}\right]_{m \times n}
$$

And the first layer fuzzy comprehensive evaluation set is:

$$
R_{i}=A R=A\left[\begin{array}{c}
B_{1} \\
B_{2} \\
\ldots \\
B_{n}
\end{array}\right]=\left[b_{1}, b_{2}, \ldots, b_{n}\right]
$$

In which $b_{k}=V\left[a_{i} \wedge r_{i k}\right],(k=1,2,3,4,5)$

6) select fuzzy composition operator of evaluating China's urban low-carbon developmental level

In fuzzy comprehensive evaluation, commonly used composition operators are main-factors-decided, main-factors-highlighted, unbalanced and weighted average, which have their own advantages and disadvantages. When practically evaluating China's urban low-carbon developmental level comprehensively, we not only overall consider the completeness of factors that influence China's urban low-carbon developmental level, but also consider the differences of the importance of each factor that influences China's urban low-carbon developmental level; therefore, calculation model selects weighted averaged composition operator.

7) Obtain evaluation results of China's urban low-carbon developmental level

The results based on Fuzzy-AHP method can be obtained through three ways: 1) maximum membership grade method; 2) fuzzy distribution method; 3) parameter method; Parameter method takes the product of $\mu_{v}$ and $B_{k}$ as 
parameter, which means $N=\mu, B \sim k T=\mu_{v}\left(b_{1} b_{2} \quad b_{3} \quad b_{4} b_{5}\right) T$, and the results of measuring China's urban low-carbon developmental level is characterized by the value of the parameter $\mathrm{N}$. In the three methods, the last one is the most direct because it uses number to express and it is the most beneficial to evaluate and compare the ranks of China's urban low-carbon developmental level and thus becomes the most common way to obtain results.

\section{Empirical analysis---take one medium-sized city in midland for example}

In order to evaluate the low-carbon level of residents in the city scientifically and accurately, the research group chose 10 persons including 4 persons from related management departments in the city, 4 persons from environmental institute and 2 central researchers in the research group to evaluate residential low-carbon developmental level in the city using the index system and evaluation model mentioned above. Through various measurement and calculation, related data about the first rank index weight $A$, the second index weight $A_{i}$ and membership grade $\mathrm{r}_{\mathrm{ijk}}(\mathrm{k}=1,2,3,4,5)$ is shown in table 1 .

Corresponding to the data above, there is

$\mathrm{A}=(0.20,0.18,0.12,0.24,0.16,0.10), \mathrm{A}_{1}=(0.05,0.20,0.20,0.20,0.05,0.25,0.05), \mathrm{A}_{2}=(0.22,0.21,0.21,0.23,0.13), \mathrm{A}_{3}=(0$.

$15,0.05,0.15,0.20,0.20,0.05,0.25,0.05), \mathrm{A}_{4}=(0.15,0.05,0.15,0.15,0.05,0.25,0.05), \mathrm{A}_{5}=(0.05,0.25,0.25,0.25,0.20), \mathrm{A}_{6}$ $=(0.30,0.20,0.20,0.20,0.10)$

$\mathrm{R}_{1}, \mathrm{R}_{2}, \mathrm{R}_{3}, \mathrm{R}_{4}, \mathrm{R}_{5}$ and $\mathrm{R}_{6}$ can be obtained through calculation formula of the membership $r_{i j k}$ and $\mathrm{R}_{\mathrm{i..}}$ And combined with the former formula $\mathrm{R}$ and $\mathrm{B}$ can be obtained:

So the first layer fuzzy comprehensive evaluation set is

$\mathrm{B}=\mathrm{AR}=[0.1491,0.2546,0.2565,0.2361,0.0857]$

$\mathrm{B}$ represents the comprehensive evaluation results of residential low-carbon developmental level in the city. In order to quantify the elements of evaluation value $V$, suppose $V_{1}=10, V_{2}=20, V_{3}=30, V_{4}=40, V_{5}=50$, $\mathrm{V}=(10,20,30,40,50)$, which means $\mathrm{V}=(10,20,30,40,50)$. Then evaluation results are weighted and $\mathrm{V}=$ $0.1491 \times 10+0.2546 \times 20+0.2565 \times 30+0.2361 \times 40+0.0857 \times 50=28.007$

From the data above we can see $\mathrm{V}<30$, which shows under the background of low-carbon economy, the low-carbon developmental level in the city is in low mediate level. Through the analysis on the distribution situation of maximum value in each row of the matrix $R$, it is clear that residential resources usage is insufficient in the city and its low-carbon production technology level is very lag behind but its low-carbon concept has begun to form. The evaluation results are in accordance with urban residential practice.

\section{Conclusions and suggestions}

Through the structure and empirical analysis of theoretical model above, the following conclusions and suggestions are obtained: Now that low-carbon development is the inevitable choice of urban development, the governmental decision-making department should formulate low-carbon development strategy plan from the height of strategy to seek for urban low-carbon development mode. As city, it should have its own evaluation index system of low-carbon development level in order to measure its low-carbon developmental level and thus find and solve problems; empirical research shows the evaluation results of the evaluation model is in accordance with urban residential practice. For the reasons, on the one hand, the urban low-carbon developmental level evaluation index system in the underground of low-carbon economy established in the article has higher effectiveness and operability; on the other hand, because fuzzy method can better solve fuzzy problems of each index factor through induction of factor set U, AHP method can better solve the problem of confirmation of weight set and thus make the evaluation model based on Fuzzy-AHP method more objective and creditable. In conclusion, both the government and urban residents must make low-carbon concept rooted in urban development strategy, positively respond to global climate changes, develop ecological civilization city and positively optimize China's urban industrial distribution.

\section{References}

Bao Jianqiang, Miao Yang, Chen Feng. (2008). Low-carbon economy: a new mode of economic development of human transformation. China's industrial economy by 2008 (4):153-160. (In Chinese)

Fan Jianhua. (2010). A low carbon economy theoretical framework and System Construction. Theoretical Exploration, 2010 (2):122-123. (In Chinese)

Gao Yang and so on. (2009). China's Zinc Industry Development Research. Hunan: Central South University Press, July 2009. (In Chinese)

Li Zhiqing (2009). "post-crisis era" and the low carbon economy. Wen Wei Po, 2009, 07, 02. (In Chinese)

Xu Guoquan, Liu Zeyuan, Zhao Hua Jiang. (2006). China's carbon emissions Decomposition Model and 
Empirical Analysis: 1995-2004. China Population Resources and Environment, 2006, 16 (6):158-161. (In Chinese)

Table 1. the evaluation information of low-carbon developmental level in one medium-sized city in midland

\begin{tabular}{|c|c|c|c|c|c|c|c|c|c|}
\hline Target layer & First index & $\begin{array}{c}\text { The weight of } \\
\text { the first index } \\
\text { A }\end{array}$ & Second index & $\begin{array}{l}\text { The } \\
\text { weight of } \\
\text { the } \\
\text { second } \\
\text { index } A_{i}\end{array}$ & $\mathrm{R}_{\mathrm{ij} 1}$ & $\mathrm{R}_{\mathrm{ij} 2}$ & $\mathrm{R}_{\mathrm{ij} 3}$ & $\mathrm{R}_{\mathrm{ij} 4}$ & $\mathrm{R}_{\mathrm{ij} 5}$ \\
\hline \multirow{12}{*}{$\begin{array}{l}\text { the evaluation } \\
\text { index system of } \\
\text { urban } \\
\text { low-carbon } \\
\text { developmental } \\
\text { level }\end{array}$} & \multirow[t]{7}{*}{$\begin{array}{c}\mathrm{U}_{1} \\
\text { Resource } \\
\text { and energy } \\
\text { system }\end{array}$} & \multirow[t]{7}{*}{0.20} & $\begin{array}{l}\text { The proportion } \\
\text { of new } \\
\text { low-carbon } \\
\text { energy in total } \\
\text { energy }\left(\mathrm{u}_{11}\right)\end{array}$ & 0.05 & 0.3 & 0.4 & 0.1 & 0.1 & 0.1 \\
\hline & & & $\begin{array}{l}\text { Comprehensive } \\
\text { energy } \\
\text { consumption of } \\
\text { unit industrial } \\
\text { added value of } \\
\text { unit }\left(\mathrm{u}_{12}\right)\end{array}$ & 0.20 & 0.1 & 0.4 & 0.3 & 0.0 & 0.2 \\
\hline & & & $\begin{array}{l}\text { Average energy } \\
\text { consumption of } \\
\text { unit GDP }\left(\mathrm{u}_{13}\right)\end{array}$ & 0.20 & 0.4 & 0.2 & 0.1 & 0.1 & 0.2 \\
\hline & & & $\begin{array}{l}\text { Urban capacity } \\
\text { to recycle mine } \\
\text { resources }\left(\mathrm{u}_{14}\right)\end{array}$ & 0.20 & 0.3 & 0.3 & 0.1 & 0.1 & 0.2 \\
\hline & & & $\begin{array}{l}\text { The recovery of } \\
\mathrm{SO}_{2} \text { in } \\
\text { enterprises } \\
\text { whose profit } \\
\text { reach } 10000 \\
\text { Yuan }\left(\mathrm{u}_{15}\right)\end{array}$ & 0.05 & 0.2 & 0.3 & 0.3 & 0.1 & 0.1 \\
\hline & & & $\begin{array}{l}\text { flexibility } \\
\text { coefficient of } \\
\text { energy } \\
\text { consumption } \\
\left(\mathrm{u}_{16}\right) \\
\end{array}$ & 0.25 & 0.3 & 0.3 & 0.2 & 0.1 & 0.1 \\
\hline & & & $\begin{array}{l}\text { The proportion } \\
\text { of architecture } \\
\text { with low energy } \\
\text { consumption } \\
\left(\mathrm{u}_{17}\right)\end{array}$ & 0.05 & 0.3 & 0.3 & 0.2 & 0.1 & 0.1 \\
\hline & \multirow{5}{*}{$\begin{array}{c}\mathrm{U}_{2} \\
\text { Economic } \\
\text { system }\end{array}$} & \multirow[t]{5}{*}{0.18} & $\begin{array}{l}\text { drive ability of } \\
\text { green production } \\
\text { area }\left(\mathrm{u}_{21}\right)\end{array}$ & 0.22 & 0.3 & 0.3 & 0.1 & 0.1 & 0.2 \\
\hline & & & $\begin{array}{l}\text { The relative } \\
\text { developmental } \\
\text { level of tertiary } \\
\text { industry }\left(\mathrm{u}_{22}\right)\end{array}$ & 0.21 & 0.2 & 0.3 & 0.2 & 0.1 & 0.2 \\
\hline & & & $\begin{array}{l}\text { disposable } \\
\text { income of } \\
\text { residents in city } \\
\text { and town }\left(\mathrm{u}_{23}\right)\end{array}$ & 0.21 & 0.3 & 0.3 & 0.2 & 0.1 & 0.1 \\
\hline & & & $\begin{array}{l}\text { GDP per capita } \\
\left(\mathrm{u}_{24}\right)\end{array}$ & 0.23 & 0.3 & 0.1 & 0.1 & 0.1 & 0.4 \\
\hline & & & $\begin{array}{l}\text { The rate of } \mathrm{CO}_{2} \\
\text { emission in } \\
\text { enterprises }\end{array}$ & 0.13 & 0.2 & 0.1 & 0.0 & 0.3 & 0.4 \\
\hline
\end{tabular}




\begin{tabular}{|c|c|c|c|c|c|c|c|c|}
\hline & & $\begin{array}{l}\text { whose profit } \\
\text { reach } 10000 \\
\text { Yuan }\left(\mathrm{u}_{25}\right)\end{array}$ & & & & & & \\
\hline \multirow[t]{8}{*}{$\begin{array}{c}\mathrm{U}_{3} \\
\text { Science and } \\
\text { technology } \\
\text { system }\end{array}$} & \multirow[t]{8}{*}{0.12} & $\begin{array}{l}\text { The proportion } \\
\text { between capture } \\
\text { and seal of } \\
\text { greenhouse } \\
\text { gases } \quad\left(\mathrm{u}_{31}\right)\end{array}$ & 0.1 & 0.3 & 0.1 & 0.1 & 0.2 & 0.3 \\
\hline & & $\begin{array}{l}\text { Low-carbon } \\
\text { technology and } \\
\text { cleaning } \\
\text { production } \\
\text { technology } \\
\left(\mathrm{u}_{32}\right) \\
\end{array}$ & 0.0 & 0.2 & 0.3 & 0.2 & 0.1 & 0.2 \\
\hline & & $\begin{array}{l}\text { The rate of } \\
\text { low-carbon } \\
\text { reform for } \\
\text { traditional } \\
\text { production } \\
\text { process }\left(\mathrm{u}_{33}\right)\end{array}$ & 0.1 & 0.2 & 0.4 & 0.3 & 0.0 & 0.1 \\
\hline & & $\begin{array}{l}\text { Comprehensive } \\
\text { usage of } \\
\text { industrial wastes } \\
\left(\mathrm{u}_{34}\right)\end{array}$ & 0.1 & 0.3 & 0.3 & 0.2 & 0.1 & 0.1 \\
\hline & & $\begin{array}{l}\text { The attainment } \\
\text { rate of the } \\
\text { industrial waste } \\
\text { water }\left(\mathrm{u}_{35}\right)\end{array}$ & 0.1 & 0.4 & 0.2 & 0.1 & 0.1 & 0.2 \\
\hline & & $\begin{array}{l}\text { life garbage } \\
\text { treatment rate } \\
\left(\mathrm{u}_{36}\right)\end{array}$ & 0.0 & 0.3 & 0.2 & 0.0 & 0.2 & 0.3 \\
\hline & & $\begin{array}{l}\text { use } \\
\text { energy-saving } \\
\text { appliances } \\
\left(\mathrm{u}_{37}\right) \\
\end{array}$ & 0.2 & 0.3 & 0.2 & 0.1 & 0.1 & 0.3 \\
\hline & & $\begin{array}{l}\text { Automation } \\
\text { level of } \\
\text { corporate } \\
\text { equipment }\left(\mathrm{u}_{38}\right)\end{array}$ & 0.0 & 0.3 & 0.2 & 0.1 & 0.1 & 0.3 \\
\hline \multirow{5}{*}{$\begin{array}{l}\text { Social } \\
\text { system }\end{array}$} & \multirow[t]{5}{*}{0.24} & $\begin{array}{l}\text { The rate of } \\
\text { publicity of } \\
\text { residential } \\
\text { low-carbon } \\
\text { concept }\left(\mathrm{u}_{41}\right)\end{array}$ & 0.1 & 0.3 & 0.2 & 0.1 & 0.1 & 0.3 \\
\hline & & $\begin{array}{l}\text { The rate of } \\
\text { publicity of } \\
\text { environmental } \\
\text { education }\left(\mathrm{u}_{42}\right)\end{array}$ & 0.0 & 0.2 & 0.1 & 0.2 & 0.4 & 0.2 \\
\hline & & $\begin{array}{l}\text { The public } \\
\text { satisfaction } \\
\text { environmental } \\
\text { protection }\left(\mathrm{u}_{43}\right)\end{array}$ & 0.1 & 0.3 & 0.2 & 0.3 & 0.2 & 0.3 \\
\hline & & $\begin{array}{l}\text { per capita } \\
\text { housing area } \\
\left(\mathrm{u}_{44}\right)\end{array}$ & 0.1 & 0.3 & 0.2 & 0.0 & 0.2 & 0.3 \\
\hline & & $\begin{array}{l}\text { The proportion } \\
\text { of } \mathrm{RD} \\
\text { investment in }\end{array}$ & 0.1 & 0.3 & 0.2 & 0.1 & 0.1 & 0.3 \\
\hline
\end{tabular}




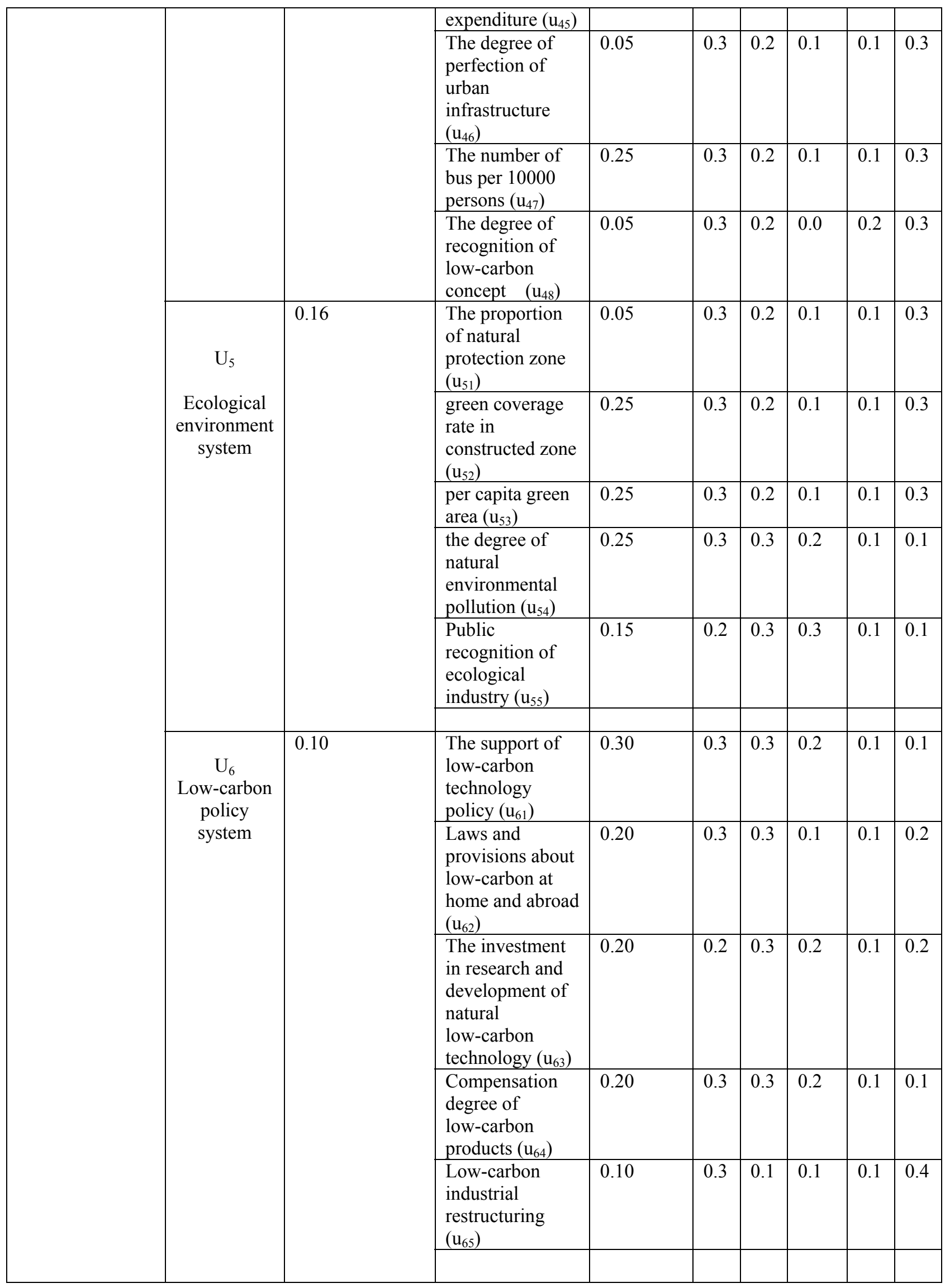

